\title{
PELATIHAN PEMASARAN RELASIONAL BERBASIS TEKNOLOGI INFORMASI ANDROID PADA PEDAGANG KUE JAJANAN TRADISIONAL DI KECAMATAN TAMALANREA, MAKASSAR
}

\author{
Android Information Technology Training-Based Relational Marketing \\ Training for Traditional Snack-Cake Traders in Tamalanrea District, Makassar
}

\author{
Kasnaeny Karim*, Ibrahim Dani \\ Program Studi Manajemen, Universitas Muslim Indonesia, Makassar \\ Jalan Urip Sumiharjo, Kota Makassar, Provinsi Sulawesi Selatan \\ *Alamat Korespondensi: kasnaeny@umi.ac.id
}

(Tanggal Submission: 20 November 2020, Tanggal Accepted: 28 Desember 2020)

\begin{abstract}
ABSTRAK
Pedagang kue tradisional di wilayah pemukiman Kecamatan Tamalanrea Makassar, di masa pandemi Covid 19 bahkan sebelumnya, tidak mampu bersaing dengan toko-toko kue yang besar dan menjual secara secara online. Hal ini diakibatkan oleh kemampuan mereka dalam teknologi yang sangat minim. Feomena yang terlihat rata-rata pedagang kue tersebut memiliki handphone (HP) Android, namun pemanfaatannya hanya sebatas mengirim pesan dan membagi hasil swa foto melalui facebook dan whatsApp. Permasalahan tersebut, memberi sinyal bahwa pelaku usaha masih memiliki pengetahuan dan kemampuan yang rendah dalam hal pengelolan produk dan pemasaran relasional dengan memanfaatkan teknologi informasi.melalui HP. Dengan demikian, kegiatan pengabdian kepada masyarakat ini bertujuan untuk: (1) membantu memperbaiki kehidupan masyarakat melalui literasi kemampuan mengakses pasar dan pemasaran relasional berbasis Android (2) Mengedukasi melalui pelatihan cara melakukan periklanan dan penjualan secara online melalui HP berbasis Android. Untuk mencapai tujuan tersebut, maka metode pembelajaran kepada peserta dilakukan melalui ceramah, diskusi, dan pelatihan, agar peserta mampu memahami maksud dan tujuan mengenai pentingnya teknologi informasi dalam mendukung pemasaran, dan mampu mempraktekkan secara mandiri cara memasarkan lewat media HP Android. Hasil kegiatan PKM ini adalah peningkatan pengetahuan dan kemampuan memanfaatkan HP Android untuk merancang iklan, menyebarkan informasi pemasaran, dan kemampuan memasarkan berbasis relasional, serta kemampuan merancang iklan. Keberlanjutan dari kegiatan ini terlihat dari terbentuknya grup pemasaran online dan dibina oleh lembaga penggiat masyarakat di Kecamatan Tamalanrea, Makassar
\end{abstract}

Kata Kunci: Pemasaran Relasional; Teknologi Informasi; Online; Handphone; Android 


\section{PENDAHULUAN}

Kecamatan Tamalanrea terbentuk sejak 7 Januari 1998 yang merupakan pemekaran dari kecamatan Biringkanaya dan memiliki luas area kurang lebih $31,84 \mathrm{~km}^{2}$ atau $18,2 \%$ dari luas Kota Makassar. Jumlah penduduk pada hingga bulan mei tahun 2015 mencapai kurang lebih 142.000 Jiwa. Kecamatan Tamalanrea merupakan kawasan pendidikan dimana terdapat Lembaga Perguruan Tinggi Negeri dan swasta yang berjumlah kurang lebih 15 (lima belas) salah satu diantaranya adalah Universitas Hasanuddin (UNHAS) yang terletak di Kelurahan Tamalanrea Indah, Kecamatan Tamalanrea juga merupakan kawasan pergudangan, pabrik dan industry yang berjumlah kurang lebih 960 (Sembilan ratus enam puluh) buah, yang terletak di Kelurahan Bira dan Kelurahan Parangloe.

Dengan kondisi tersebut, maka terdapat banyak pemukiman baik untuk hunian tetap ataupun sewaan. Kondisi tersebut menyebabkan bertumbuhnya usaha makanan dan minuman mengingat banyak penduduk yang bekerja menetap dengan sistem sewa, akibat kesibukan tidak lagi memiliki waktu untuk memasak. Ramainya penjual makanan khususnya kue-kue tradisional terlihat di pagi hari sebelum masyarakat beraktivitas, baik dikantor ataupun di kampus.

Banyaknya penjual kaki lima yang berjualan kue-kue tradisional menyebabkan tingkat persaingan menjadi tinggi. Meskipun kue-kue tersebut dijual dengan harga murah (Rp. 1.000,-/biji), namun menurut seorang informan, jika sore hari banyak tersisa kue-kue yang akhirnya menjadi basi. Kondisi ini diperparah dengan adanya wabah covid 19, yang menyebabkan penjualan di pagi hari pun sepi pembeli. Dengan demikian dapat terlihat bahwa terdapat kerugian pada pelaku usaha rumahan tersebut. Jika ditelusuri, perilaku penjualan kue-kue tersebut masih mengikuti pola yang sudah ada, yakni berjualan di depan rumah, di pinggir jalan, atau menitipkan kuekue di toko tanpa mengetahui bagaimana kondisi memasarkan produk yang harus disesuaikan dengan kondisi lingkungan, serta apa yang menjadi kebutuhan konsumen pada saat kondisi seperti ini. Hal ini telah dinyatakan oleh Kotler \& Keller, (2012) serta Solomon et al., (2007), bahwa dalam memasarkan produk harus memperhatikan faktor lingkungan internal dan eksternal konsumen, dimana salah satunya adalah dampak lingkungan, baik lingkungan budaya, sosial, dan teknologi.

Menurut informasi awal yang didapatkan, rata-rata pelaku usaha kue masih berfikir pada pola lama yakni "semua tergantung rezeki" sehingga meski produk tidak terjual, mereka tidak menganggap kondisi tersebut sebagai kerugian, padahal telah mengeluarkan biaya produksi yang tidak sedikit. Pelaku usaha belum memiliki kemampuan untuk melakukan pemasaran secara modern dan mengenalkan produknya kepada masyarakat di luar wilayah tempat tinggal mereka. Kondisi ini sesuai dengan pernyataan Suyono \& Purnomo, (2013), bahwa beberapa keterbatasan yang dimiliki UKM antara lain terkait dengan pembiayaan, survival mentality, penyusunan rencana strategis, informasi pasar secara memadai, dan kepiawaian (expertise) dalam pemasaran.

Untuk itu, penting bagi pelaku usaha untuk mempelajari bagaimana cara memasarkan produk yang tidak lagi mengandalkan penjualan di wilayah sekitar. Untuk itu diperlukan strategi pemasaran relasional. Pemasaran relasional adalah upaya yang dilakukan oleh perusahaan untuk mendapatkan dan mempertahankan pelanggan dengan menciptakan komunikasi dua arah dan mengelola suatu hubungan yang saling menguntungkan antara pelanggan dan 
perusahaan. Menurut Chan (2003: 87) yang dikutip oleh Nikmah, (2017), "Relationship marketing atau pemasaran relasional ditujukan untuk menciptakan pengenalan bagi setiap pelanggan secara lebih dekat melalui komunikasi dua arah dengan mengelola suatu hubungan yang saling menguntungkan antara pelanggan dan perusahaan". Sementara menurut Semuel, (2012), Customer relationship marketing atau CRM adalah salah satu bentuk kualitas layanan yang diukur melalui komitmen, komunikasi, dan penanganan keluhan. Pada hakekatnya relationship marketing terdiri dari tiga pendekatan yaitu: ikatan keuangan, ikatan sosial, dan ikatan structural (Widjaja, 2016).

Dengan demikkan, PKM ini bertujuan untuk memperluas distribusi produk melalui strategi pemasaran relasional berbasis Android. Selain peningkatan kemampuan memanfaatkan teknologi, juga bertujuan untuk meingkatkan kesejahteraan pelaku industri rumah tangga. Manakala pemasar kue tradisional makin mahir memanfaatkan HP android dalam melakukan penjualan, diharapkan akan mampu memperkenalkan produknya kepada lingkungan yang lebih luas dan mampu bersaing dengan pemasar online yang telah ada.

Permasalahan Mitra yang ditemukan setelah mengidentifikasi fenomena, adalah minimnya pengetahuan terkait pemasaran secara lebih luas, yang diuraikan sebagai berikut:

a. Pelaku industri rumah tangga khususnya pembuat kue-kue tradisional di kelurahan Tamalanrea Jaya belum dapat dikatakan sejahtera.

b. Tidak mampu mengakses pasar yang lebih luas.

c. Tidak mampu berhubungan langsung dengan konsumen di luar wilayah mereka

d. Minimnya pengetahuan mengenai pemanfaatan teknologi informasi dalam melakukan transaksi dan distribusi, meski sebagian besar telah memilik Handphone Android

e. Minimnya pengetahuan mengenai cara merubah pola pemasaran berdasarkan kondisi lingkungan.

\section{METODE PELAKSANAAN}

1. Tahap Sosialisasi

Pada tahap ini dilakukan observasi awal terkait kegiatan yang akan dilakukan. Setelah melakukan observasi melalui narasumber dan informasi-informasi dari media massa, maka Tim PKM membuat proposal terkait apa yang akan dilakukan beserta maksud dan tujuannya, serta luaran yang dihasilkan. Setelah pembuatan proposal selesai maka Tim PKM mencari mitra yang dapat menjadi pendukung dan pemberi informasi serta dapat membantu pelaksanaan kegiatan. Setelah mendapatkan mitra, maka tim melakukan sosialisasi terkait kegiatan yang akan dilaksanakan. Setelah pemaparan mengenai maksud dilakukannya PKM pada desa Mitra, maka dilakukan penandatanganan kontrak kerjasama antara Tim PKM dengan mitra. Tahap sosialisasi hingga penandatanganan kontrak ini diperkirakan memakan waktu 2 bulan.

2. Tahap Penyusunan Metode Kegiatan

$$
\text { Pada tahap penyusunan }
$$
metode kegiatan ini terlebih dahulu mencari tahu faktor yang dapat mendukung keberhasilan pembelajaran. Berdasarkan beberapa kajian, keinginan seseorang untuk belajar sangat ditentukan oleh tenaga pendidik dalam hal ini pemateri, yakni sebagai fasilitator, motivator, sumber 
belajar, dan organisator dalam proses pembelajaran, sehingga guru hendaknya dapat menerapkan berbagai strategi dan metode yang tepat guna membantu para peserta dalam memahami konsep pembelajaran yang diajarkan, serta dapat membuat peserta senang dan tertarik untuk mempelajarinya mengingat yang akan dilatih adalah kalangan yang sudah lama tidak perah bersentuhan dengan pendidikan secara formal.

Selain itu perlu pendekatan dengan menggunakan media yang paling mereka sukai, dengan demikian maka metode kegiatan ini dilakukan semenarik mungkin yang akan diselingi dengan pertunjukan melalui video terkait masalah mitra. Untuk memastikan mitra mampu menggunakan aplikasi android, maka disiapkan metode pembelajaran yang dilakukan dengan praktek langsung hingga mahir.

3. Tahap Pelaksanaan

Agar kegiatan ini dapat berjalan dengan baik dan lancar maka terlebih dahulu dilakukan kontrak dengan membuat kesepakatan waktu dan tempat kegiatan antara calon peserta dengan tim pelaksana. Program ini akan dilaksanakan selama tiga bulan dengan frekuesi tiga kali pertemuan tiap pekan. Mengingat yang akan dilatih adalah para pembuat dan pedagang kue, maka kegiatan ini akan dilakukan pada siang hari pada pukul 10.00-16.30 WITA (setelah mempersiapkan dagangannya).

4. Monitoring dan Evaluasi
Agar tujuan PKM berhasil, maka seluruh bentuk kegiatan yang dilaksanakan akan dipantau secara berlanjut untuk melihat kesesuaiannya dengan rencana yang terlah disusun. Adapun spesifikasi kegiatan monitoring yang dilakukan adalah:

a. Peserta

- Kehadiran peserta

- Keaktifan selama pembelajaran

- Kemampuan dalam menangkap materi

b. Pelaksana program/Pendamping

- Meninjau dan melihat proses pembelajaran dan perkembangan yang terjadi.

- Melihat dan meninjau keaktifan peserta.

- Mendampingi peserta selama kelas pembelajaran berlangsung.

- Mengarahkan peserta apabila terjadi kekeliruan

Kegiatan evaluasi dilakukan dua kali, yaitu evaluasi dalam jangka waktu tertentu (tiap kegiatan selesai) dan evaluasi akhir program. Evaluasi dalam jangka waktu tertentu dilakukan untuk menilai arah dan kemajuan program, efisiensi dan efektifitas program, dan berbagai kendala yang ditemui saat program berlangsung. Sementara evaluasi akhir program dilakukan untuk menilai hasil yang telah dicapai selama pelaksanaan program untuk kemudian disusun menjadi laporan akhir kegiatan.

5. Keberlanjutan Program

Agar program ini dapat terus berlanjut, maka tim pelaksana akan melakukan kerja sama dengan 
pemerintah setempat untuk menjadikan kegiatan pelatihan ini berkelanjutan. Selain itu, dengan terbentuknya kelompok-kelompok usaha nantinya akan membuka kesempatan bagi konsumen untuk langsung membeli pada kelompok yang telah ada sesuai dengan produk yang diinginkan.

6. Partisipasi Mitra Partisipasi mitra dalam
kegiatan PKM ini adala mengumpulkan informasi-informasi awal terkait masalah yang dihadapi oleh mitra. Untuk selanjutnya mitra diminta kesediaannya untuk memberi sosialisasi kepada seluruh petani kopi, bawang dan garam terkait kegiatan PKM ini, dan memastikan bahwa masyarakat bersedia menerima dan mau mengikuti pembelajaran yang akan dilaksanakan. Pada saat kegiatan pembelajaran selama 3 bulan, mitra dapat membantu memberi motivasi pada peserta agar tidak jenuh, dan mempertemukan dengan pemerintah setempat yang akan diajak kerjasama terkait keberlanjutan kegiatan.

\section{Ringkasan Materi}

Materi yang akan diberikan dalam bentuk ceramah, diskusi, dan pelatihan.

- Materi bacaan diberikan secara online dengan memberikan link kepada peserta.

- Ceramah yang dilakukan untuk memberi pemahaman mengenai kegiatan-kegiatan yang dilakukan dalam pemasaran produk, bentukbentuk distribusi langsung dan tidak langsung, materi motivasi dalam meningkatkan kualitas Sumber Daya Manusia, dan pemasaran relasional.

- Diskusi dilakukan setelah diskusi dan setelah selesainya praktek

- Pelatihan/Praktek diberikan setelah materi ceramah telah selesai dengan langsung mempraktekkan pada media yang dimiliki oleh peserta berupa handphone atau laptop bagi yang memiliki, dan yang akan diajarkan adalah cara melakukan pemasaran relasional secara online.erisi lokasi dan partisipasi kegiatan, bahan dan alat, metode penyelesaian masalah, analisis situasi, metode pendekatan/pelaksanaan kegiatan yang diterapkan, permasalahan mitra yang akan diselesaikan. Jika merupakan penerapan teknologi industri maka diuraikan konsep dan komponen program dalam pelaksanaan kegiatan.

\section{HASIL DAN PEMBAHASAN}

Pelatihan dilakukan di masa new normal pandemi Covid19, maka kegiatan tetap dilangsungkan dengan mengikuti ketentuan protokol kesehatan, yakni, mencuci tangan, memakai masker, dan menjaga jarak. Hal ini terlihat saat registrasi, peserta diminta untuk mencuci tangan, dilanjutkan dengan pembagian masker. Kursi di dalam aula pelatihan di atur dengan memperhatikan jarak antara satu peserta dengan peserta yang lain. 


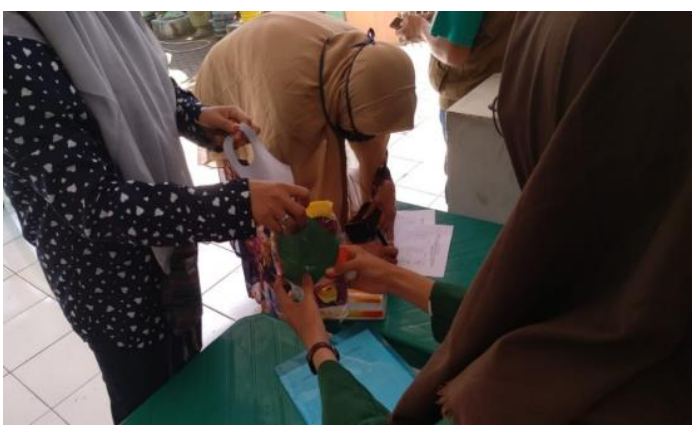

Gambar 1. Aktivitas Registrasi dan Pembagian Masker ke Peserta

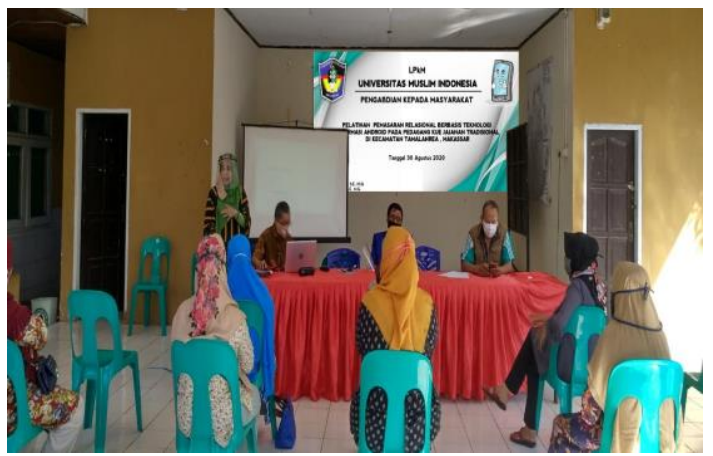

Gambar 2. Suasana Pelatihan

Materi yang disampaikan dalam penyuluhan dan pelatihan ini dilakukan melalui ceramah, diskusi dan praktek langsung pada media HP. Adapun kegiatan didahului dengan pengenalan mengenai pemasaran relasional. Tahapan selanjutnya adalah pelatihan dalam membuat iklan, dan tahapan akhir adalah cara melakukan unggah iklan ke media sosial, dan pengenalan marketplace. Pelatihan ini dilakukan dengan menghadirkan narasumber terkait teknologi IT dan pelaku usaha online yang telah memiliki pengalaman dalam pembuatan iklan produk.

\section{Materi Pemasaran Relasional}

Pemasaran relasional atau relationship marketing merupakan sebuah strategi yang dilakukan oleh perusahaan untuk dapat mengenal dan melayani konsumen dengan baik, yang berdasar pada hubungan yang lebih dekat dengan menciptakan komunikasi dua arah dan mengelola hubungan yang saling menguntungkan antara perusahaan dengan konsumen (Pantow et al., 2018). Pada dasarnya seseorang telah memiliki hubungan dengan orang lain baik di lingkungan terdekat maupun jauh, dengan demikian seorang pemasar dapat memanfaatkan hubungan yang ada dalam memasarkan produk mereka. Memasarkan berdasarkan hubungan memang memerlukan komunikasi, dan seorang pemasar dapat memanfaatkan hubungan yang ada dengan mengkomunikasikan produk mereka dengan beriklan melalui media online, sehingga tidak diperlukan lagi tatap muka.

Materi pertama berisi sosialisasi, yang bertujuan memberi pengetahuan kepada peserta mengenai apa yang dimaksud dengan pemasaran relasional dan apa saja yang harus dperhatikan saat melakukan pemasaran. Mitra diperkenalkan tentang bauran pemasaran, misalnya apa yang perlu diperhatikan saat pembuatan produk, dan memberi pengetahuan mengenai cara melakukan penetapan harga, cara melakukan distribusi, dan merancang periklanan (Kotler,2012). Peserta diajarkan mengenai pentingnya memperhatikan bauran pemasaran, terutama periklanan dalam mendukung pemasaran online.

\section{Pelatihan Pembuatan Iklan dan Pemotretan Produk}

Pelatihan pembuatan iklan dan teknik pemotretan produk untuk iklan, dilakukan agar peserta mampu menampilkan produk mereka lebih menarik dibanding produk lain yang juga melakukan pemasaran online. Membuat iklan tidak boleh dilakukan secara seadanya, akan tetapi bagaiman sebuah iklan mampu memberikan informasi secara sekaligus mengenai bentuk produk, harga, manfaat, cara memperolehnya dalam selembar gambar, namun sudah tercakup keseluruhan informasi 
yang dibutuhkan oleh konsumen. Iklan sangat berguna untuk meposisikan produk dan merupakan sebuah strategi pemasaran (Kotler dan Keller, 2012, dan Karadeniz, 2009). Peserta diajarkan cara melakukan pemotretan dengan bahan yang murah tapi mampu menghasilkan gambar yang bersih dan menarik, dengan hanya menggunakan kertas kartun atau kain dengan warna tertentu. Perbandingan Foto yang dibuat seadanya dengan foto yang menggunakan media kertas kartun juga dapat dilihat pada GAmbar 4 dan Gambar 5.

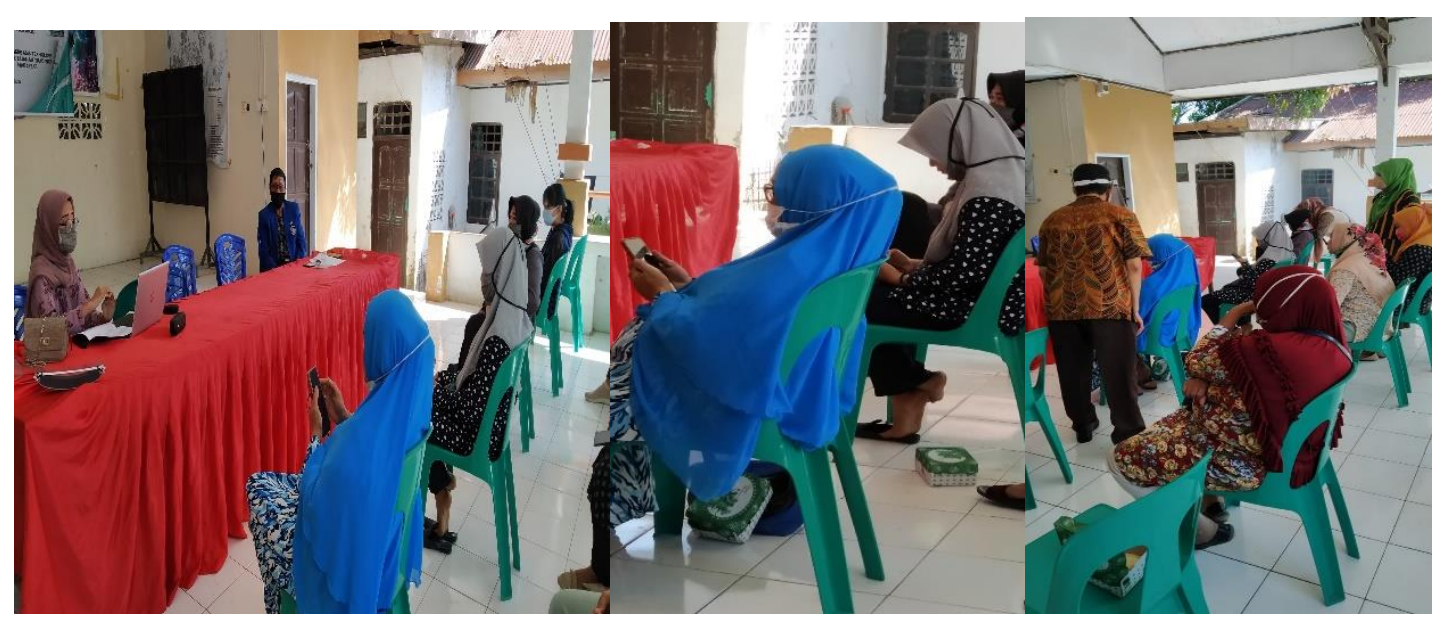

Gambar 3. Suasana saat pelatihan

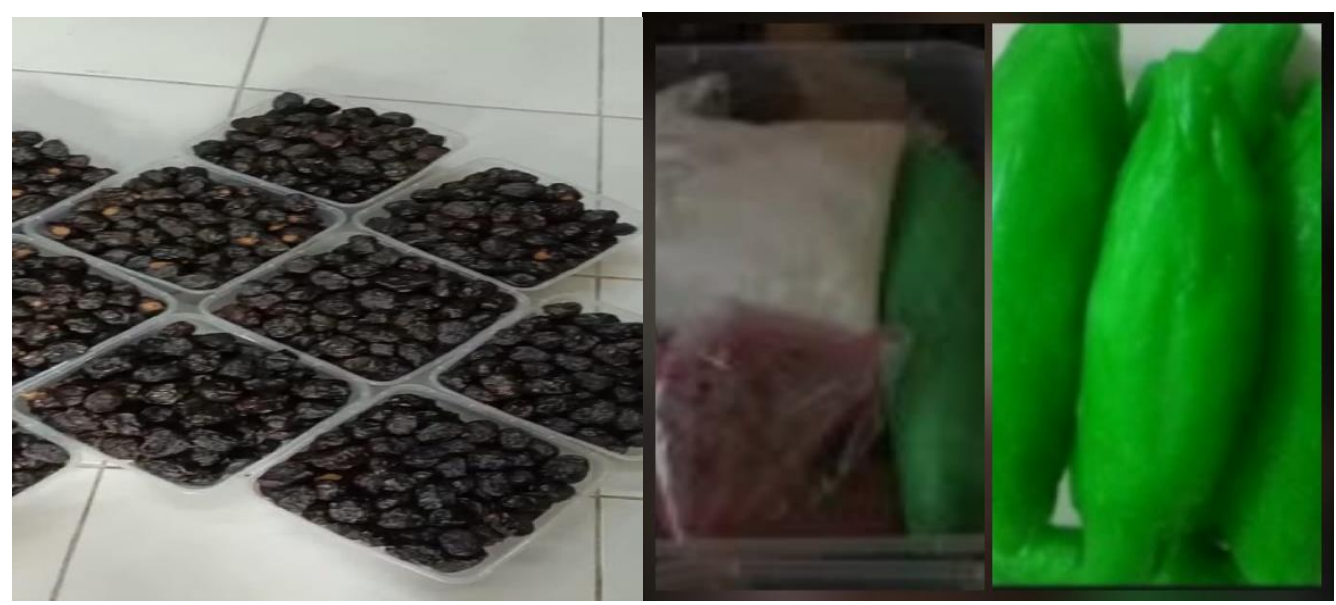

Gambar 4. Pemotretan produk tanpa menggunakan media, dipotret langsung dari lantai

Kesan yang ditumbulkan oleh gambar di atas adalah akan memunculkan kesan produk yang tidak bersih karena hanya diletakkan dilantai, sementara produk yang dijual adalah makanan. Bagi sebagian besar masyarakat Bugis Makassar menganggap makanan tidak sepantasnya di letakkan di lantai, sehingga dalam melakukan pembelian produk masih mempertimbangkan kebiasaan yang diajarkan oleh leluhur (Kasnaeny, 2016). 


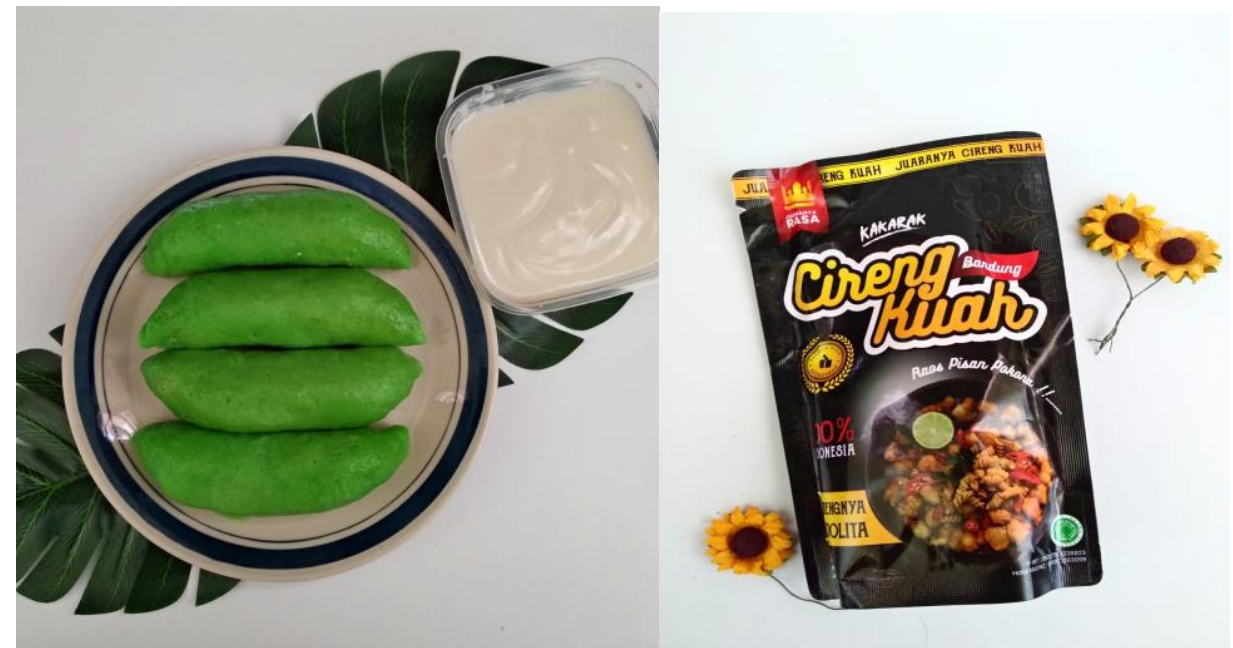

Gambar 5. Produk yang di potret menggunakan media kertas kartun

\section{Pelatihan Cara Unggah ke Media Sosial dan Pengenalan Market Place}

Setelah dilakukan praktek pembuatan gambar produk, maka dilanjutkan dengan materi pelatihan menguggah iklan ke marketplace. Beberapa sasaran yang dapat dituju secara online yakni whatsApp, Instagram, dan facebook, yang tidak lupa dijelaskan mengenai luas pasar yang dapat dijangkau. Selain itu dikenal dengan marketplace yang dapat dituju yaitu, gobiz, Lazada, Tokopedia, Shopee, Buka lapak, dan lain-lain). Pada materi ini peserta diperkenalkan juga dengan content creating berupa Canva dan Picsaypro. Kurangnya kemampuan peserta mengenai pasar-pasar online yang ada, maka pada pelatihan ini lebih berfokus pada penggunaan facebook, WA, Instagram dan Telegram. Hal ini diakibatkan peserta baru mendengar hal tersebut.

Kegiatan PKM ini telah dapat menambah pengetahuan dan wawasan serta melatih kemahiran peserta dalam menggunakan dan memanfaatkan Handphone Android yang dimiliki. Luaran dari PKM ini berupa peningkatan kemampuan peserta dalam melakukan pemasaran secara online, baik melalui WhatsApp, Instagram, dan facebook yang sudah dikenal selama ini namun belum termanfaatkan, dan mempersiapkan sumberdaya yang diperlukan jika ingin menyasar Tokopedia, Shopee, dan lainnya.

Dari 15 peserta yang hadir, 12 peserta tekun melaksanakan pelatihan sesuai petunjuk dan panduan narasumber. Narasumber yang dihadirkan untuk melatih peserta adalah yang memiliki kemampuan di bidang IT dan praktisi yang berkecimpung dalam pelaksanaan pemasaran online. Materi pelatihan diajarkan mulai dari cara menyiapkan media untuk pemotretan produk terkait iklan, cara melakukan marketplace melalui toko-toko online, misalnya shopee, buka lapak, gobis, tokopedia, dan lainnya. Peserta juga diajarkan apa yang harus diperhatikan jika melalukan postingan iklan di whatsApp, facebook, dan instagram.

Output kegiatan lainnya yang terbentuk adalah kelompok dagang online, yang akan didampingi perjalanan dan perkembangannya oleh lembaga masyarakat di kelurahan Tamalanrean Jaya, Makassar. Grup dagang online yang terbentuk diakhir kegiatan bernama "Kuliner Tamalanrea Jaya". Meskipun masih sederhana namun telah menumbuhkan niat dari peserta untuk memulai melakukan 
pemasaran secara online, yang beranggotakan relasi-relasi terdekat mereka.

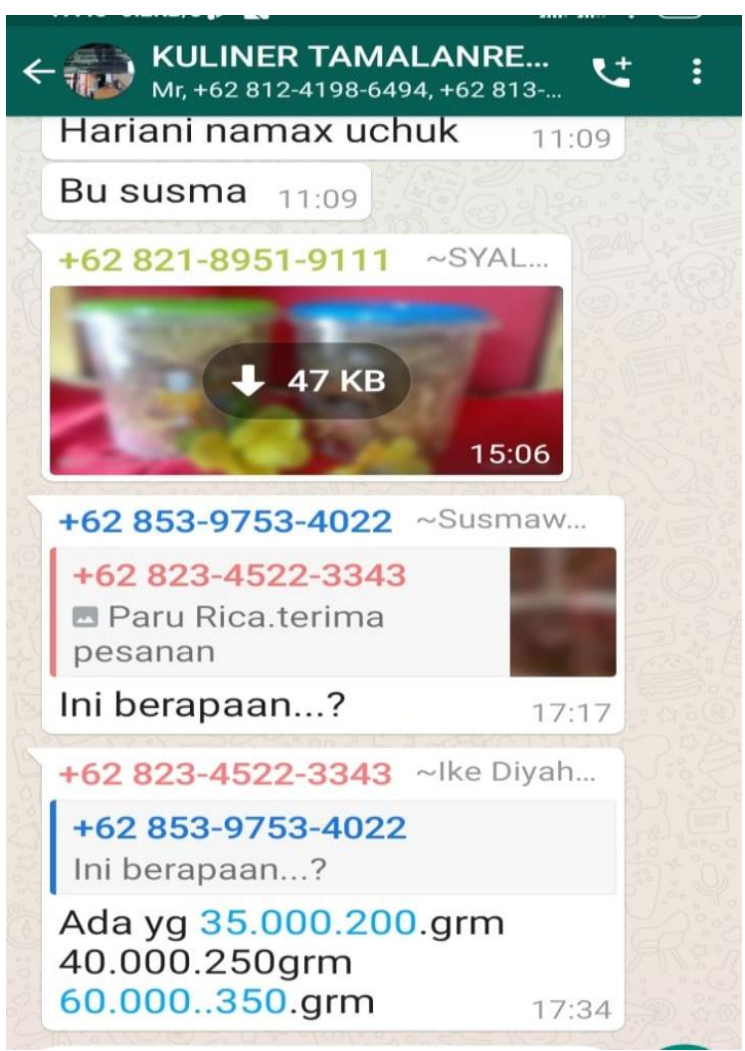

Gambar 6 . Percakapan penjualan produk

Gambar di atas merupakan grup dagang online sederhana melalui WhatsApp Group (WA), yang merupakan hasil tindaklanjut dari kegiatan pelatihan yang dibina oleh pendamping UMKM di Tamalanrea.

\section{Kendala Saat Pelatihan}

Pada saat pelatihan diperlukan upaya yang keras dari pemateri dan pelaksana kegiatan PKM, akibat peserta masih awam tentang istilah-istilah dan cara melakukan browsing untuk mendapatkan materi. Hal ini dimaklumi karena peserta hanya terbiasa menggunakan media sosial untuk bercengkrama dan berkirim foto diri. Kendala lainnya adalah beberapa peserta telah berusia di atas 50 tahunan dan memiliki penglihatan yang sudah tidak jelas, sehingga diperlukan waktu dan pendamping tersediri dalam hal ini meminta bantuan dari mahasiswa yang turut menjadi anggota Tim PKM. Mengingat pembatasan waktu yang diberikan oleh pemerintah setempat untuk tidak berkumpul terlalu lama dalam rangka mencegah penularan Covid 19, maka untuk mengatasi kendala yang dialami oleh peserta, dibentuklah grup WA untuk berkomunikasi secara langsung jika ada kendala atau ada yang belum dipahami secara sempurna.

Kegiatan Pengabdian Kepada Masyarakat yang dilaksanakan oleh Tim PKM FEB Universitas Muslim ini, sangat diapresiasi oleh peserta, mengingat kegiatan ini baru pertama kali diadakan di wilayah mereka. Hasil angket yang dikumpulkan, rata-rata peserta berharap ada kelanjutan dari pelatihan ini, untuk makin memahirkan mereka dalam berdagang melalui media android. Pelaksanaan kegiatan ini berjalan lancar atas dukungan kelurahan Tamalanrea Jaya dan Penggerak masyarakat, yang menyatakan bahwa akan terus memantau kelompok kuliner online yang telah terbentuk, untuk terus berkegiatan sehingga dapat membantu perekonomian keluarga. Peserta yang sudah paham dengan materi yang diajarkan langsung mengunggah iklan produknya beberapa saat setelah pelatihan dan telah mendapatkan respon dari pembeli di sekitar mereka yang telah mereka kenal. Dengan demikian pemasaran melalui media sosial telah membantu pedagang rumahan untuk melakukan pemasaran relasional

\section{KESIMPULAN DAN SARAN}

Kesimpulan dari kegiatan PKM ini adalah:

1. Terjadi peningkatan kemampuan dalam mengakses pasar yang lebih luas, sehingga berdampak terhadap perbaikan ekonomi dan kehidupan 
masyaakat, melalui penggunaan HP Android

2. Terjadi peningkatan kemampuan masyarakat dalam melakukan periklanan dan penjualan secara online, serta meningkatkan kepercayaan diri masyarkat sebagai dampak kemampuan menghasilkan gambar iklan produk yang menarik melalui melalui HP berbasis Android.

Saran yang diberikan:

1. Pemerintah setempat dan pendamping UMKM agar dapat melakukan pendampingan lanjutan agar peserta dapat makin mahir dalam menggunakan perangkat HP dalam melakukan pemasaran online. pelatihan sejenis yang ditujukan kepada kelompok usia yang lebih muda dan produktif, agar dapat terjadi keberlanjutan usaha orangtua atau yang telah ada.

2. Pengabdi selanjutnya dapat melakukan kegiatan serupa di masa akan datang dengan berfokus pada merujuk kepada kegiatan yang belum dapat dilaksanakan pakelompok usia yang lebih muda, karang taruna atau usaha lain, yang belum dilaksanakan pada PKM ini.

\section{UCAPAN TERIMA KASIH}

Ucapan terimakasih disampaikan kepada semua pihak yang telah terlibat dan turut menyukseskan pelaksanaan PKM ini. Ucapan terimakasih kami tujukan kepada: (1). Lembaga Pengabdian Kepada Masyarakat (LPkM) Universitas Muslim Indonesia, yang telah memberikan bantuan dana melalui Hibah PKM Internal Dosen UMI, (2) Kepala Kelurahan Tamalanrea Jaya, yang mendukung dan memfasilitasi kegiatan ini, (3) Bapak Ir. Muhammad Taqwin, sebagai penggerak UMKM di Tamalanrea Jaya dan terus membimbing masyarakat untuk meningkatkan pendapatan keluarga, (4) Narasumber yang telah bersedia meluangkan waktu meskipun di tengah wabah pendemi Covid19.

\section{DAFTAR PUSTAKA}

Karadeniz, M..2009. Product Positioning Strategy In Marketing Management. Deniz Bilimleri ve Mühendisliği Dergisi, 5(2), 98-110.

Kasnaeny, K. 2016. Customer Decision Making Style, Based On Bugis - Makassar Culture in Indonesia. International Journal of Business and Management Invension, 5(3), 1-6. https://www.ijbmi.org/papers/Vol(5)3/V ersion-2/A503020106.pdf

Kotler, Philiph., \& Keller, K. L. .2012. Marketing Management. In S. Yagan (Ed.), Prentice Hall (14th ed., Vol. 22, Issue 4). Prentice Hall.

https://doi.org/10.1080/0891176090302 2556

Nikmah, N. R. 2017. Hubungan Relationship Marketing, Customer Satisfaction Dan Customer Loyalty. Kompetensi, 11(2), 196-209.

Pantow, F. S., Tumbuan, W. J. F. ., \& Ogi, I. W. .2018. Analisis Pemasaran Relasional Terhadap Loyalitas Pelanggan Rumah Kayu Manado Pada Pt. Woloan Permai Perkasa. Jurnal EMBA: Jurnal Riset Ekonomi, Manajemen, Bisnis Dan Akuntansi, 6(3), 1618-1627. https://doi.org/10.35794/emba.v6i3.203 21

Semuel, Hatane. 2012. Customer Relationship Marketing Pengaruhnya Terhadap. Jurnal Manajemen Pemasaran, 7(1), 33-41. https://doi.org/10.9744/pemasaran.7.5. 33-41

Solomon, M., Bamossy, G., Askegaard, S., \& 
Hogg, M. K. 2007. Consumer Behaviour: A European Perspective. In Pharmacy world \& science : PWS (Fifth Edit, Vol. 29, Issue 1). Original fifth edition, entitled Consumer Behavior published by Prentice-Hall, Inc.,. https://doi.org/10.1007/s11096-0053797-z

Suyono, \& Purnomo, H. .2013. Jaringan Relasional Vertikal Dan Horizontal Batik Tanjung Bumi. Jurnal Dan Prosiding
Universitas Jenderal Soedirman (JP Feb Unsoed), 3(3), 2013.

Widjaja, C. O. .2016. Pengaruh Relationship Marketing Terhadap Customer Loyalty Dan Customer Satisfaction Sebagai Variabel Intervening Pada Pt. Fuboru Indonesia Di Surabaya. Jurnal Manajemen Pemasaran, 10(2), 52-58. https://doi.org/10.9744/pemasaran.10.2 $.52-58$ 